Article

\title{
Immobilization of penicillin $G$ acylase on paramagnetic polymer microspheres with epoxy groups
}

\author{
Xing Chen, Lu Yang, Wangcheng Zhan *, Li Wang, Yun Guo, Yunsong Wang, Guanzhong Lu, \\ Yanglong Guo \# \\ Key Laboratory for Advanced Materials and Research Institute of Industrial Catalysis, School of Chemistry and Molecular Engineering, East China \\ University of Science and Technology, Shanghai 200237, China
}

\section{A R T I C L E I N F O}

\section{Article history:}

Received 22 August 2017

Accepted 13 October 2017

Published 5 January 2018

\section{Keywords:}

Paramagnetic polymer microspheres

Epoxy groups

Penicillin G acylase

Covalent bonding

Immobilization

\begin{abstract}
A B S T R A C T
Paramagnetic polymer microspheres were synthesized by the inverse suspension polymerization method through polymerization of glycidyl methacrylate, ally glycidyl ether and methacrylamide on the surface of silica-coated $\mathrm{Fe}_{3} \mathrm{O}_{4}$ nanoparticles using $N, N^{\prime}$-methylene-bis(acrylamide) as a cross-linking agent. Penicillin G acylase (PGA) was covalently immobilized on the surface of the paramagnetic microspheres by reacting the amino groups of the PGA molecules with the epoxy groups of the paramagnetic polymer microspheres. The effect of the $\mathrm{SiO}_{2}$ coating and the amount of paramagnetic $\mathrm{Fe}_{3} \mathrm{O}_{4}$ nanoparticles on the initial activity and the operational stability of the immobilized PGA was investigated. The results indicated that $\mathrm{SiO}_{2}$ played an important role in the polymerization process and paramagnetic polymer microspheres with a $\mathrm{SiO}_{2}$-coated $\mathrm{Fe}_{3} \mathrm{O}_{4}$ nanoparticles mass content of $7.5 \%$ are an optimal support material for PGA immobilization. Immobilized PGA on the paramagnetic polymer microspheres shows a high initial activity of $430 \mathrm{U} / \mathrm{g}$ (wet) and retains 99\% of its initial activity after recycling 10 times. Furthermore, immobilized PGA exhibits high thermal stability, pH stability and excellent reusability, which can be rapidly recycled by the aid of magnet.
\end{abstract}

(C) 2018, Dalian Institute of Chemical Physics, Chinese Academy of Sciences. Published by Elsevier B.V. All rights reserved.

\section{Introduction}

Penicillin G acylase (PGA) is an important industrial biocatalyst that is widely used for the enzymatic production of 7aminodeacetoxycephalosporanic acid and 6-amimopenicillanic acid, which are the major pharmaceutical intermediates for producing semisynthetic $\beta$-lactam antibiotics $[1,2]$. However, the stability and reusability of PGA are major drawbacks that have restricted its wide industrial application [3,4]. Therefore, as an industrial biocatalyst, it is extremely urgent to immobilize PGA on solid supports to obtain recoverable and stable heterogeneous biocatalysts. Many kinds of supports have been reported for the immobilization of PGA, including acrylic resins [5], aldehyde-agarose [6], gelatin-chitosan [7], magnetic polymer beads [8], functionalized silica [9] and mesoporous silica [10-12].

The optimal support material for the immobilization of PGA should meet the following requirements: (1) A high density of

\footnotetext{
* Corresponding author. Tel/Fax: +86-21-64252923; E-mail: zhanwc@ecust.edu.cn

\# Corresponding author. Tel/Fax: +86-21-64252923; E-mail: ylguo@ecust.edu.cn

This work was supported by the National Natural Science Foundation of China (91545103), Shu Guang Project of Shanghai Municipal Education Commission and Shanghai Education Development Foundation (10SG30), and the Fundamental Research Funds for the Central Universities (222201717003).

DOI: 10.1016/S1872-2067(17)62934-6 | http://www.sciencedirect.com/science/journal/18722067 | Chin. J. Catal., Vol. 39 , No. 1, January 2018
} 
reactive groups on the support surface for multipoint grafting of enzymes [13] and (2) a large surface area to immobilize more enzymes on the support surface [14]. In general, the surface area can be increased by decreasing the particle size of the support. However, support materials with a small particle size are difficult to separate from the reaction mixture by conventional methods. For example, GAMM support with epoxy groups can meet the first requirement mentioned above and has been used as a support for covalent immobilization of PGA and glucose isomerase $[15,16]$. However, with a decrease in the particle size, the reuse of GAMM support in the substrate by filtration is time-consuming and inconvenient. Magnetic separation is an attractive alternative to centrifugation or filtration. Therefore, among all supports, magnetic materials have attracted increasing attention for the immobilization of enzymes. Magnetic supports are mainly magnetic silica composites and polymer microspheres, which are prepared by encapsulating magnetic particles in a silica shell or in organic polymers $[17,18]$. Yang et al. [19] prepared paramagnetic aldehyde-functionalized mesostructured cellular foams (PAMCFs) by grafting 3-aminopropyltriethoxysilane-modified $\mathrm{Fe}_{3} \mathrm{O}_{4}$ $\left(\mathrm{NH}_{2}-\mathrm{Fe}_{3} \mathrm{O}_{4}\right)$ nanoparticles on the outer surface of aldehyde-functionalized mesostructured cellular foams (AMCFs). PGA/PAMCFs-15 showed a high initial activity of $9563 \mathrm{U} / \mathrm{g}$ and retained $89.1 \%$ of its initial activity after it was recycled 10 times. Furthermore, PGA/PAMCFs can be easily recycled by a magnetic field instead of tedious separation by high-speed centrifugation that is usually used for mesoporous materials.

Herein, we prepared paramagnetic polymer microspheres as supports for the immobilization of PGA to combine the excellent properties of polymer microspheres with the unique paramagnetic properties of magnetic nanoparticles [20]. The magnetic nanoparticles were synthesized by a coprecipitation method, and then the paramagnetic polymer microspheres were synthesized by inverse suspension polymerization with glycidyl methacrylate (GMA), ally glycidyl ether (AGE) and acrylamide in the presence of silica-coated $\mathrm{Fe}_{3} \mathrm{O}_{4}$ nanoparticles. The structure, composition and morphology of the paramagnetic polymer microspheres were characterized by Fourier transform infrared spectroscopy (FT-IR), scanning electron microscopy (SEM), X-ray diffraction (XRD), vibrating sample magnetometry and nitrogen sorption. The initial activity, operational stability, thermal stability and $\mathrm{pH}$ stability of the immobilized PGA were investigated.

\section{Experimental}

\subsection{Chemicals}

Penicillin G acylase $(520 \mathrm{U} / \mathrm{mL})$ was purchased from Zhejiang Haider Co. Ltd., Jinhua, China. Penicillin G potassium salt was purchased from CSPS Heibei Zhongrun Pharmaceutical Co. Ltd., Shijiazhuang, China. Tetraethyl orthosilicate (TEOS) and ammonium hydroxide (25 wt\%) were bought from Shanghai Lingfeng Chemical Reagent Co. Ltd., Shanghai, China. Other reagents were of analytical grade and obtained from Sinopharm Chemical Reagent Co. Ltd., Shanghai, China.

\subsection{Synthesis of paramagnetic polymer microspheres}

\subsubsection{Preparation of magnetic $\mathrm{Fe}_{3} \mathrm{O}_{4}$ nanoparticles}

$\mathrm{Fe}_{3} \mathrm{O}_{4}$ nanoparticles were prepared by a conventional coprecipitation method [21]: $0.0137 \mathrm{~mol}$ of $\mathrm{FeCl}_{3} \cdot 6 \mathrm{H}_{2} \mathrm{O}$ and $0.0075 \mathrm{~mol}$ of $\mathrm{FeSO}_{4} \cdot 7 \mathrm{H}_{2} \mathrm{O}$ were dissolved in $100 \mathrm{~mL}$ of deionized water in a three-neck flask under a nitrogen atmosphere and then the mixture was heated to $65^{\circ} \mathrm{C}$ under mechanical stirring. Then, aqueous ammonia (25 wt \%) was added dropwise into the solution until the $\mathrm{pH}$ value reached 11.0. After the mixture was stirred at $65{ }^{\circ} \mathrm{C}$ for $2 \mathrm{~h}$, the $\mathrm{Fe}_{3} \mathrm{O}_{4}$ nanoparticles (designated as $\mathrm{Fe}_{3} \mathrm{O}_{4}$ ) were separated from the mixture by the aid of magnet, washed several times with deionized water until the $\mathrm{pH}$ decreased to 7.0 and then dried at $60^{\circ} \mathrm{C}$ under vacuum for $12 \mathrm{~h}$.

\subsubsection{Preparation of $\mathrm{SiO}_{2}$-coated magnetic $\mathrm{Fe}_{3} \mathrm{O}_{4}$ nanoparticles}

The $\mathrm{SiO}_{2}$-coated magnetic $\mathrm{Fe}_{3} \mathrm{O}_{4}$ nanoparticles were prepared by the Stober method [22]. $1.5 \mathrm{~g}$ of $\mathrm{Fe}_{3} \mathrm{O}_{4}$ nanoparticles were added into the mixture composed of $120 \mathrm{~mL}$ of ethanol, $30 \mathrm{~mL}$ of deionized water and $3.75 \mathrm{~mL}$ of aqueous ammonia (25 wt\%). The suspension was vibrated ultrasonically and then $2.1 \mathrm{~g}$ of TEOS was slowly added into the suspension under continuous stirring. After stirring at room temperature for $12 \mathrm{~h}$, the $\mathrm{SiO}_{2}$-coated magnetic $\mathrm{Fe}_{3} \mathrm{O}_{4}$ nanoparticles (designated as $\mathrm{Fe}_{3} \mathrm{O}_{4} / \mathrm{SiO}_{2}$ ) were separated by the aid of a magnet, washed with deionized water until the $\mathrm{pH}$ reached 7.0 and then dried at $60^{\circ} \mathrm{C}$ under vacuum for $12 \mathrm{~h}$.

\subsubsection{Preparation of paramagnetic polymer microspheres}

The paramagnetic polymer microspheres were prepared by the inverse suspension polymerization method [23]. Typically, $1.07 \mathrm{~g}$ of a mixture of Span-60 and Tween-20 (8:3, mass ratio) was added into $120 \mathrm{~mL}$ of the mixed solvent of $n$-heptane and tetrachloroethylene (3:1, volume ratio) in a glass flask. Then, $28 \mathrm{~g}$ of the mixture composed of $\mathrm{Fe}_{3} \mathrm{O}_{4} / \mathrm{SiO}_{2}$ nanoparticles, GMA, AGE, $N, N^{\prime}$-methylene-bis(acrylamide), methacrylamide and carboxamide (1:2:2:7:1:20, mass ratio) was added into the glass flask within 2 min with $0.55 \mathrm{~g}$ of azobisisobutyronitrile as an initiator under a nitrogen atmosphere. After the resulting mixture was reacted at $55^{\circ} \mathrm{C}$ for $4 \mathrm{~h}$, the produced paramagnetic polymer microspheres were separated with the aid of a magnet and washed with ethanol several times. Finally, the paramagnetic polymer microspheres were extracted with 50 $\mathrm{mL}$ of ethanol for $48 \mathrm{~h}$ and $50 \mathrm{~mL}$ of $n$-heptane for $48 \mathrm{~h}$ successively and dried at $60^{\circ} \mathrm{C}$ under vacuum for $12 \mathrm{~h}$.

\subsection{Immobilization of PGA}

$0.1 \mathrm{~g}$ of paramagnetic polymer microspheres was added to 5 $\mathrm{mL}$ of PGA solution that was diluted with phosphate buffer (1 $\left.\mathrm{mol} / \mathrm{L}, \mathrm{pH}=7.5, V_{\text {buffer: }} V_{\mathrm{PGA}}=5.25: 1\right)$. The mixture was incubated in a water bath at $28{ }^{\circ} \mathrm{C}$ for $12 \mathrm{~h}$ at a rotating speed of $150 \mathrm{r} / \mathrm{min}$. Then, immobilized PGA was separated with the aid of a magnet and washed with phosphate buffer $(0.1 \mathrm{~mol} / \mathrm{L}, \mathrm{pH}$ $=7.5$ ) to remove the noncovalently coupled enzymes. The wet immobilized PGA was stored at $4{ }^{\circ} \mathrm{C}$ for the subsequent testing 
of the activity and operational stability.

\subsection{Determination of enzyme activity and operational stability}

Hydrolyzing penicillin G potassium salt (PGK) by immobilized PGA can produce the same molar amount of 6-amimopenicillanic acid and phenylacetic acid (PAA). Thus, the activity of immobilized PGA can be obtained by measuring the volume of $\mathrm{NaOH}$ solution consumed to titrate PAA in a given time. The procedure of testing the specific activity of immobilized PGA was as follows [15]: $2.5 \mathrm{~g}$ of PGK was dissolved in $47.5 \mathrm{~mL}$ of phosphate buffer $(0.02 \mathrm{~mol} / \mathrm{L}, \mathrm{pH}=8.0)$ in a water bath at $28{ }^{\circ} \mathrm{C}$, and then $0.15 \mathrm{~g}$ of wet immobilized PGA was added. The mixed solution was titrated with $\mathrm{NaOH}$ solution $(0.1$ $\mathrm{mol} / \mathrm{L}$ ) to maintain $\mathrm{pH}=8.0$. The hydrolysis procedure was continued for $10 \mathrm{~min}$, and the volume of $\mathrm{NaOH}$ solution consumed during the last $5 \mathrm{~min}$ was recorded. The specific activity of wet immobilized PGA was calculated as follows:

$$
\mathrm{A}(U / g)=\frac{C_{\mathrm{NaOH}} \times V_{\mathrm{NaOH}} \times 1000}{m t}
$$

$V_{\mathrm{NaOH}}$ is the volume of $\mathrm{NaOH}$ solution consumed $(\mathrm{mL}) ; C_{\mathrm{NaOH}}$ is the concentration of $\mathrm{NaOH}$ solution (mol/L); $m$ is the weight of wet immobilized PGA (g); $t$ is the reaction time (min), i.e., 5 min.

The operational stability of the immobilized PGA was tested as follows: After testing the initial specific activity, immobilized PGA was separated with the aid of a magnet and washed with phosphate buffer $(0.1 \mathrm{~mol} / \mathrm{L}, \mathrm{pH}=7.5)$. Then, the activity of the immobilized recycled PGA was tested by the abovementioned method.

\subsection{Characterization of materials}

Powder XRD patterns were recorded on a Bruker AXS D8 Focus diffractometer operated at $40 \mathrm{kV}, 40 \mathrm{~mA}\left(\mathrm{Cu} K_{\alpha}\right.$ radiation, $\lambda=0.15406 \mathrm{~nm}$ ). FT-IR spectra were recorded on a Nicolet Nexus 670 FT-IR spectrometer. Magnetic susceptibility was determined on a Lakeshore 7407 Vibrating Sample Magnetometer at room temperature. The morphology of the microspheres was observed by JEOL JSM-6360LV SEM. $\mathrm{N}_{2}$ adsorption-desorption isotherms were obtained at $-196{ }^{\circ} \mathrm{C}$ on a Micromeritics ASAP 2020M surface area and porosity analyzer. Prior to the measurements, the sample was vacuum-degassed at $100{ }^{\circ} \mathrm{C}$ for $12 \mathrm{~h}$.

\section{Results and discussion}

\subsection{Performance of immobilized PGA}

\subsubsection{Effect of magnetic microsphere supports}

Table 1 shows the effect of the $\mathrm{SiO}_{2}$ coating on the performance of the immobilized PGA on $\mathrm{Fe}_{3} \mathrm{O}_{4}$ /GAMM supports. Immobilized PGA on $\mathrm{Fe}_{3} \mathrm{O}_{4} / \mathrm{SiO}_{2} /$ GAMM support showed a higher initial activity (430 U/g) and better operational stability (99\%) than PGA on $\mathrm{Fe}_{3} \mathrm{O}_{4} / \mathrm{GAMM}$ support. The reason is that the magnetic $\mathrm{Fe}_{3} \mathrm{O}_{4}$ nanoparticles without a $\mathrm{SiO}_{2}$ coating tend to aggregate and are unevenly dispersed into the polymer micro-

\section{Table 1}

Performance of immobilized PGA on $\mathrm{Fe}_{3} \mathrm{O}_{4} / \mathrm{GAMM}$ and $\mathrm{Fe}_{3} \mathrm{O}_{4} / \mathrm{SiO}_{2} /$ GAMM supports.

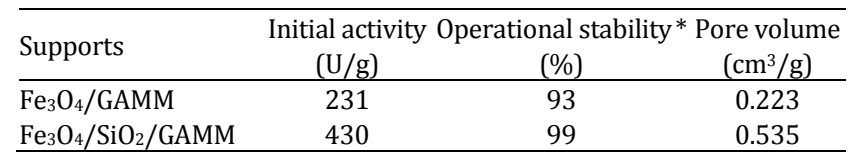

* Defined as the ratio of the activity of immobilized PGA recycled 10 times to its initial activity.

spheres. As a result, magnetic $\mathrm{Fe}_{3} \mathrm{O}_{4}$ aggregates exist in the pores of the polymer microspheres, leading to a decrease in the number of sites for PGA immobilization and a decrease in the initial activity of immobilized PGA on the $\mathrm{Fe}_{3} \mathrm{O}_{4} /$ GAMM support. Furthermore, some polymer microspheres had no magnetic $\mathrm{Fe}_{3} \mathrm{O}_{4}$ nanoparticles embedded in them, leading to a loss of immobilized PGA during the recycled experiments owing to the difficulty in separating immobilized PGA without magnetic properties from the reaction mixture. Consequently, the operational stability of the $\mathrm{Fe}_{3} \mathrm{O}_{4} /$ GAMM support was lower than that of the $\mathrm{Fe}_{3} \mathrm{O}_{4} / \mathrm{SiO}_{2} / \mathrm{GAMM}$ support. Moreover, owing to the high abundance of silanol groups on the surface of the $\mathrm{SiO}_{2}$ coating, the $\mathrm{SiO}_{2}$-coated magnetic $\mathrm{Fe}_{3} \mathrm{O}_{4}$ nanoparticles $\left(\mathrm{Fe}_{3} \mathrm{O}_{4} / \mathrm{SiO}_{2}\right)$ were easily and highly dispersed in the hydrophilic monomer phase during the preparation process of the paramagnetic polymer microspheres, which can overcome the disadvantage of the parent $\mathrm{Fe}_{3} \mathrm{O}_{4}$ nanoparticles [22].

\subsubsection{Effect of $\mathrm{Fe}_{3} \mathrm{O}_{4} / \mathrm{SiO}_{2}$ content}

Fig. 1 shows the performance of immobilized PGA on the paramagnetic polymer microspheres with different $\mathrm{Fe}_{3} \mathrm{O}_{4} / \mathrm{SiO}_{2}$ contents. As shown in Fig. 1, the initial activity of the immobilized PGA decreased with increasing $\mathrm{Fe}_{3} \mathrm{O}_{4} / \mathrm{SiO}_{2}$ content in the paramagnetic polymer microspheres. The reason is that more pores of the paramagnetic polymer microspheres were occupied by $\mathrm{Fe}_{3} \mathrm{O}_{4} / \mathrm{SiO}_{2}$ nanoparticles with increasing the $\mathrm{Fe}_{3} \mathrm{O}_{4} / \mathrm{SiO}_{2}$ content, leading to a decrease in the amount of PGA immobilized in the pores of the magnetic microspheres and a decrease in the initial activity of immobilized PGA on the $\mathrm{Fe}_{3} \mathrm{O}_{4} / \mathrm{SiO}_{2} / \mathrm{GAMM}$ support. In contrast, the operational stabil-

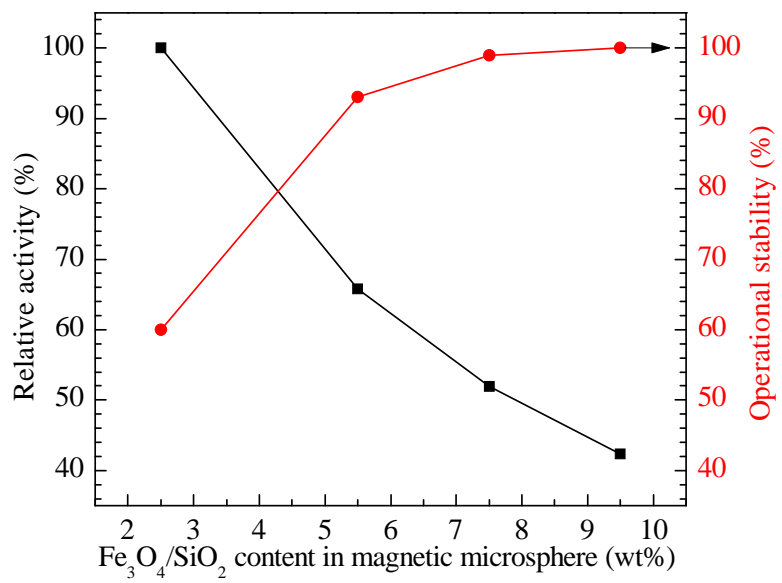

Fig. 1. Effect of $\mathrm{Fe}_{3} \mathrm{O}_{4} / \mathrm{SiO}_{2}$ content in the magnetic microspheres on the relative activity and operational stability of immobilized PGA. 


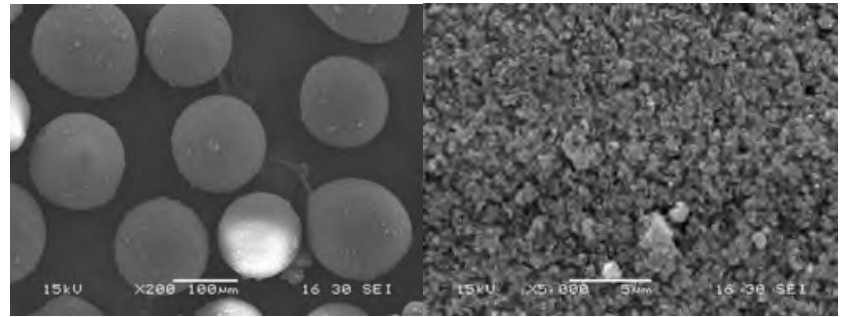

Fig. 2. SEM images of the paramagnetic polymer microspheres.

ity of immobilized PGA on the $\mathrm{Fe}_{3} \mathrm{O}_{4} / \mathrm{SiO}_{2} /$ GAMM support showed a reverse trend to the relative activity of immobilized PGA. In other words, the operational stability of immobilized PGA increased with increasing $\mathrm{Fe}_{3} \mathrm{O}_{4} / \mathrm{SiO}_{2}$ content in the paramagnetic polymer microspheres. As shown in Fig. 1, when the mass content of $\mathrm{Fe}_{3} \mathrm{O}_{4} / \mathrm{SiO}_{2}$ in the paramagnetic polymer microspheres was $2.5 \%$, the relative activity of the immobilized PGA decreased to $60 \%$ after it was recycled 10 times. However, the relative activity of immobilized PGA hardly decreased after 10 cycles when the mass content of $\mathrm{Fe}_{3} \mathrm{O}_{4} / \mathrm{SiO}_{2}$ in the paramagnetic polymer microspheres was increased to $7.5 \%$. Therefore, from the viewpoint of the operational stability, the optimum mass content of $\mathrm{Fe}_{3} \mathrm{O}_{4} / \mathrm{SiO}_{2}$ in the paramagnetic polymer microspheres was $7.5 \%$. All subsequent characterizations were carried out for paramagnetic polymer microspheres with a $\mathrm{Fe}_{3} \mathrm{O}_{4} / \mathrm{SiO}_{2}$ mass content of $7.5 \%$.

\subsection{Characterization of paramagnetic polymer microspheres}

\subsubsection{SEM}

Fig. 2 shows the surface morphology of the paramagnetic polymer microspheres. As shown in Fig. 2, the paramagnetic polymer microspheres exhibited a spherical shape with a rough surface, and their diameters were in the range of $100-150 \mu \mathrm{m}$.

\subsection{2. $\quad F T-I R$}

Fig. 3 shows FT-IR spectra of the paramagnetic polymer microspheres. The absorption band at $596 \mathrm{~cm}^{-1}$ was assigned to

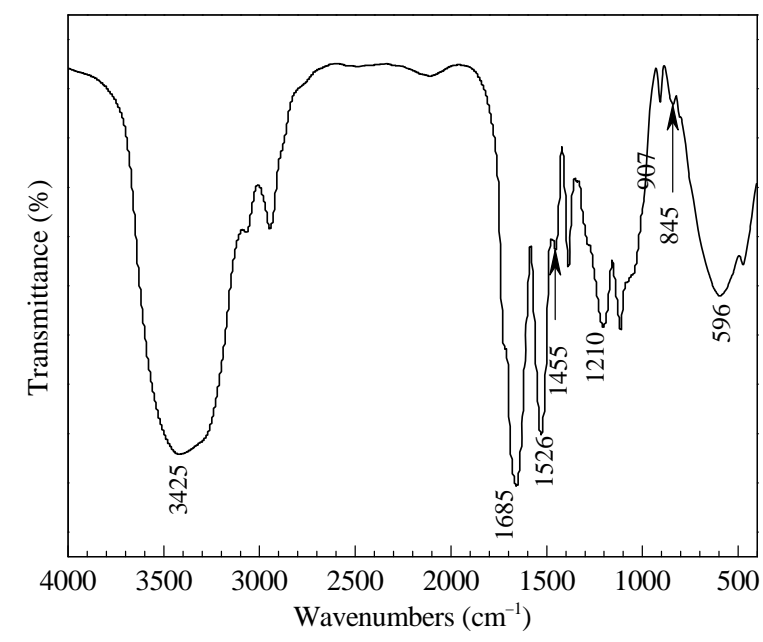

Fig. 3. FT-IR spectra of the paramagnetic polymer microspheres. the stretching vibration of the $\mathrm{Fe}-\mathrm{O}$ bond of the parent $\mathrm{Fe}_{3} \mathrm{O}_{4}$ nanoparticles [24], and the absorption bands at 907 and 845 $\mathrm{cm}^{-1}$ were assigned to epoxy groups. The absorption band at $1210 \mathrm{~cm}^{-1}$ was attributed to the $\mathrm{C}-\mathrm{O}-\mathrm{C}$ asymmetric stretching vibration of the ester group of GMA, whereas the strong absorption band at $3425 \mathrm{~cm}^{-1}$ was attributed to the $\mathrm{N}-\mathrm{H}$ stretching vibration of acylamides (MBAA, MAA). In addition, the absorption bands at 1685, 1526 and $1455 \mathrm{~cm}^{-1}$ were assigned to the stretching vibrations of $\mathrm{C}=\mathrm{O}, \mathrm{C}-\mathrm{N}, \mathrm{N}-\mathrm{H}$ in MBAA and MAA, respectively [15]. Therefore, it can be concluded that the copolymer has been formed and coated on the surface of the magnetic microspheres.

\subsection{3. $X R D$}

Fig. 4 shows XRD patterns of $\mathrm{Fe}_{3} \mathrm{O}_{4}, \mathrm{Fe}_{3} \mathrm{O}_{4} / \mathrm{SiO}_{2}$ and the magnetic polymer microspheres. The XRD patterns of all the samples exhibited six characteristic diffraction peaks assigned to (220), (311), (400), (422), (511) and (440), which were in agreement with that of the standard $\mathrm{Fe}_{3} \mathrm{O}_{4}$ crystals with a spinel structure [25]. The XRD pattern of $\mathrm{Fe}_{3} \mathrm{O}_{4} / \mathrm{SiO}_{2}$ sample hardly changed compared with the $\mathrm{Fe}_{3} \mathrm{O}_{4}$ sample, which indicated that the crystal structure of $\mathrm{Fe}_{3} \mathrm{O}_{4}$ was completely retained after $\mathrm{Fe}_{3} \mathrm{O}_{4}$ was coated with $\mathrm{SiO}_{2}$. Moreover, in addition to the diffraction peaks related to $\mathrm{Fe}_{3} \mathrm{O}_{4}$ crystals, a wide diffraction peak at $20^{\circ}-30^{\circ}$, assigned to amorphous polymer, appeared in the XRD pattern of the paramagnetic polymer microspheres, which further confirmed the existence of copolymer on the surface of the magnetic microspheres.

\subsubsection{Magnetic properties}

Fig. 5 shows the magnetization curve of the paramagnetic polymer microspheres. The magnetic polymer microspheres exhibited an apparent superparamagnetism without any hysteresis at room temperature. The superparamagnetic property was also deduced from the low residual magnetization and coercivity values [26]. The saturation magnetization (Ms) of the paramagnetic polymer microspheres was $5.0 \mathrm{emu} / \mathrm{g}$. As shown

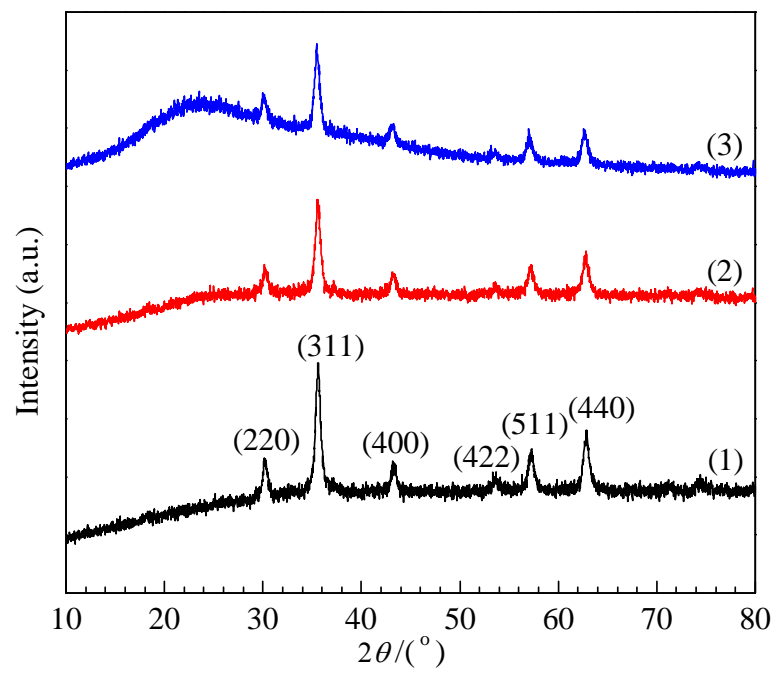

Fig. 4. XRD patterns of $\mathrm{Fe}_{3} \mathrm{O}_{4}(1), \mathrm{Fe}_{3} \mathrm{O}_{4} / \mathrm{SiO}_{2}(2)$ and the paramagnetic polymer microspheres (3). 


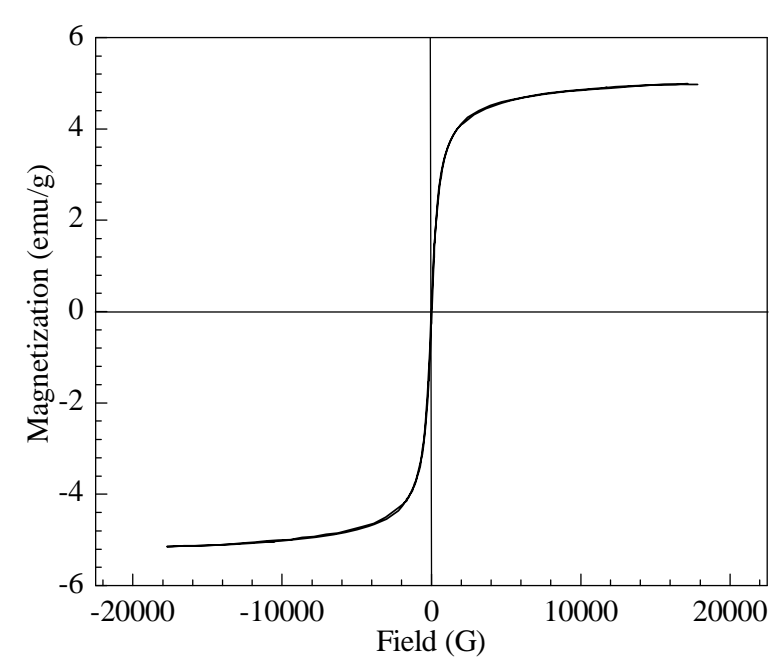

Fig. 5. Magnetization curve of the paramagnetic polymer microspheres at room temperature.

in Fig. 6, immobilized PGA on the paramagnetic polymer microspheres could be rapidly separated within $1 \mathrm{~s}$ with the aid of a magnet, which made the recycling operation more convenient.

\subsection{Stability of immobilized PGA}

The thermal stability, pH stability and reusability of the immobilized PGA are very important criteria for its industrial applications. To determine the thermal stability of the PGA immobilized on the paramagnetic polymer microspheres, the relative activities of free and immobilized PGA were tested after incubation in phosphate buffer $(0.02 \mathrm{~mol} / \mathrm{L}, \mathrm{pH}=8.0)$ at different temperatures $\left(30-65^{\circ} \mathrm{C}\right)$ for $1 \mathrm{~h}$. Similarly, to determine the $\mathrm{pH}$ stability of immobilized PGA, the relative activities of free and immobilized PGA were tested after incubation at 28 ${ }^{\circ} \mathrm{C}$ in phosphate buffer at different $\mathrm{pH}$ values (4.0-11.0) for $1 \mathrm{~h}$.

Fig. 7 shows the thermal stability and pH stability of free and immobilized PGA on the paramagnetic polymer microspheres. As shown in Fig. 7(a), although both the relative activities of free and immobilized PGA decreased with increasing incubation temperature, the thermal stability of the immobilized PGA was much better than that of free PGA. After it was incubated at $55{ }^{\circ} \mathrm{C}$ for $1 \mathrm{~h}$, immobilized PGA could retain $91 \%$ of its initial activity, whereas free PGA only retained $8.1 \%$ of its initial activity. The increase in the thermal stability may be

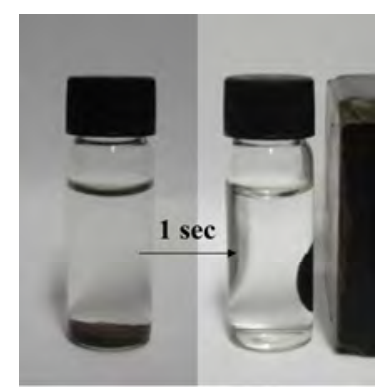

Fig. 6. Separation of immobilized PGA on the paramagnetic polymer microspheres with the aid of a magnet.
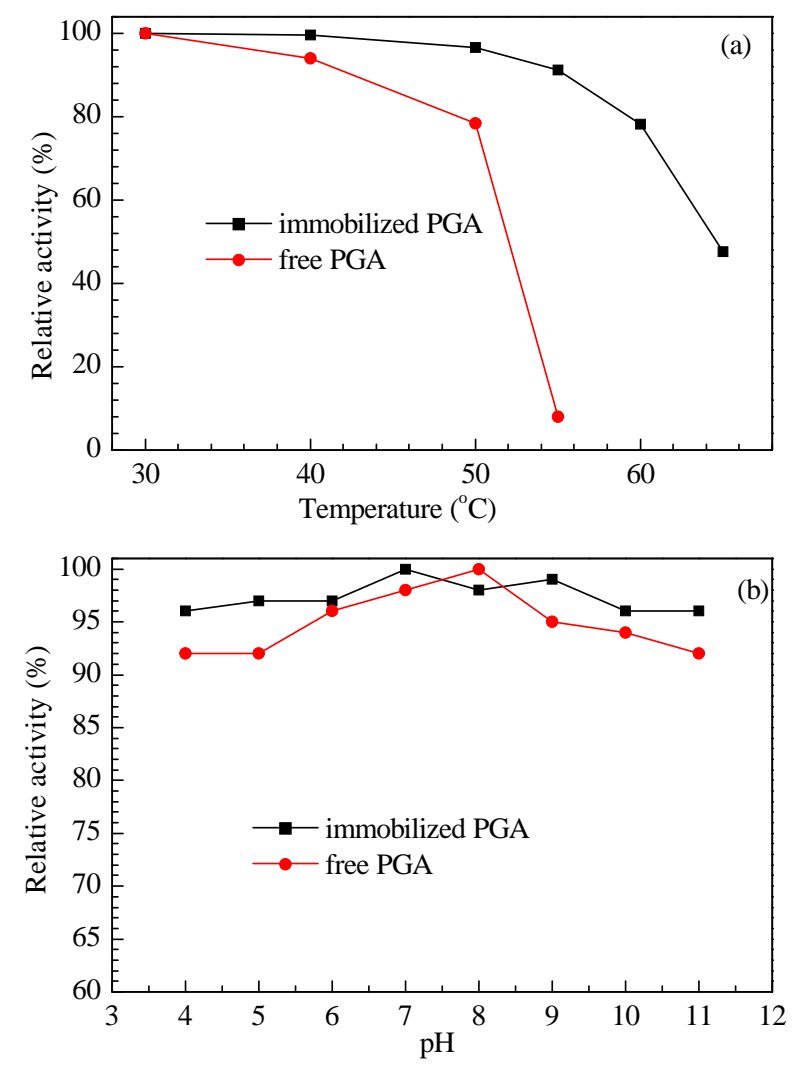

Fig. 7. The thermal stability (a) and $\mathrm{pH}$ stability (b) of free and immobilized PGA on the paramagnetic polymer microspheres.

owing to reinforcement of the weak intermolecular forces and the prevention of PGA autolysis [27]. As shown in Fig. 7(b), both the relative activities of free and immobilized PGA first increased and then decreased with increasing $\mathrm{pH}$ value of phosphate buffer. The optimum $\mathrm{pH}$ values of phosphate buffer were approximately 8.0 and 7.0 for free and immobilized PGA, respectively. Furthermore, immobilized PGA showed a wider $\mathrm{pH}$ operating window than free PGA. These results indicated that the immobilization of PGA on paramagnetic polymer microspheres by reacting the amino groups of the PGA molecules with the epoxy groups of paramagnetic supports provided high thermal stability and $\mathrm{pH}$ stability in extreme environments [28].

Fig. 8 shows the operational stability of immobilized PGA on the paramagnetic polymer microspheres. The initial activity of the immobilized PGA was $430 \mathrm{U} / \mathrm{g}$ (wet) and it could retain $99 \%$ of its initial activity after it was recycled 10 times, indicating very good reusability.

\section{Conclusions}

Paramagnetic polymer microspheres with active epoxy groups were prepared by the inverse suspension polymerization method. $\mathrm{SiO}_{2}$ played an important role in the polymerization process and its coating on the surface of $\mathrm{Fe}_{3} \mathrm{O}_{4}$ nanoparticles influenced the performance of the immobilized PGA. Immobilized PGA on the paramagnetic polymer microspheres 


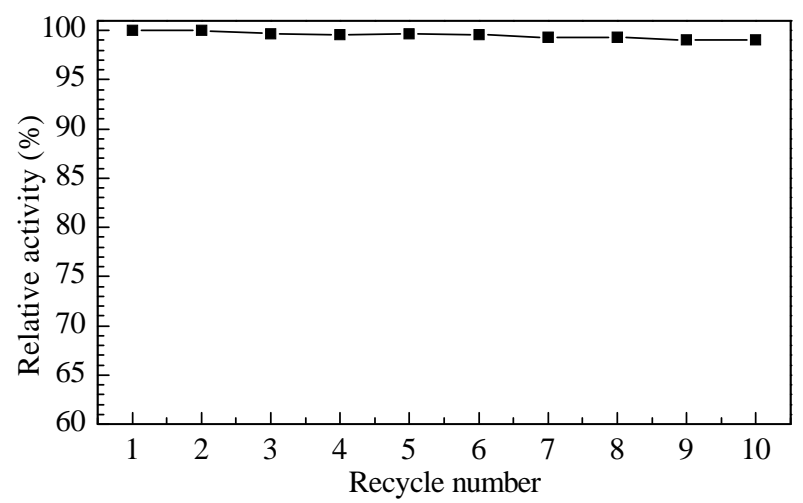

Fig. 8. The operational stability of immobilized PGA on the paramagnetic polymer microspheres.

showed a high initial activity of $430 \mathrm{U} / \mathrm{g}$ (wet) and retained $99 \%$ of its initial activity after it was recycled 10 times. The material could be conveniently recycled from the reaction medium with the aid of a magnet. Furthermore, compared with free PGA, the immobilization of PGA through the reaction of the amino groups of the PGA molecules with the epoxy groups of the paramagnetic polymer microspheres resulted in a high thermal stability and $\mathrm{pH}$ stability in extreme environments. Therefore, PGA immobilized on paramagnetic polymer microspheres is an excellent potential catalyst for industrial applications.

\section{References}

[1] X. G. Luo, L. N. Zhang, Biomacromolecules, 2010, 11, 2896-2903.

[2] A. I. Kallenberg, F. van Rantwijk, R. A. Sheldon, Adv. Synth. Catal., 2005, 347, 905-926.

[3] R. A. Sheldon, Adv. Synth. Catal., 2007, 349, 1289-1307.
[4] D. Brady, J. Jordaan, Biotechnol. Lett., 2009, 31, 1639-1650.

[5] E. Katchalski-Katzir, D. M. Kraemer, J. Mol. Catal. B, 2000, 10, 157-176.

[6] C. Mateo, J. M. Palomo, G. Fernandez-Lorente, J. M. Guisan, R. Fernandez-Lafuente, Enzyme Microb. Technol., 2007, 40, 1451-1463.

[7] B. Krajewska, Enzyme Microb. Technol., 2004, 35, 126-139.

[8] S. H. Xuan, Y. X. J. Wang, K. C. F. Leung, K. Y. Shu, J. Phys. Chem. C, 2008, 112, 18804-18809.

[9] E. Calleri, G. Massolini, D. Lubda, C. Temporini, F. Loiodice, G. Caccialanza, J. Chromatogr. A, 2004, 1031, 93-100.

[10] W. C. Zhan, Y. J. Lü, L. Yang, Y. L. Guo, Y. Q. Wang, Y. Guo, G. Z. Lu, Chin. J. Catal., 2014, 35, 1709-1715.

[11] P. Xue, G. Z. Lu, Y. L. Guo, Y. S. Wang, Y. Guo, J. Mol. Catal. B, 2004, 30, 75-81.

[12] Z. Y. Gao, W. C. Zhan, Y. L. Guo, Y. S. Wang, Y. Guo, G. Z. Lu, J. Mol. Catal. B, 2014, 105, 111-117.

[13] Z. Y. Gao, W. C. Zhan, Y. S. Wang, Y. Guo, L. Wang, Y. L. Guo, G. Z. Lu, Microporous Mesoporous Mater., 2015, 202, 90-96.

[14] U. Hanefeld, L. Gardossi, E. Magner, Chem. Soc. Rev., 2009, 38, 453-468.

[15] D. L. Wu, Q. L. Zhao, Y. L. Guo, Y. Wang, Y. S. Wang, W. C. Zhan, G. Z. Lu, Chin. J. Catal., 2010, 31, 586-590.

[16] H. T. Yu, Y. L. Guo, D. L. Wu, W. C. Zhan, G. Z. Lu, J. Mol. Catal. B, 2011, 72, 73-76.

[17] W. Wang, L. Deng, Z. H. Peng, X. Xiao, Enzyme Microb. Technol., 2007, 40, 255-61

[18] J. Lee, Y. Lee, J. K. Youn, H. B. Na, T. Yu, H. Kim, S. M. Lee, Y. M. Koo, J. H. Kwak, H. G. Park, H. N. Chang, M. Hwang, J. G. Park, J. Kim, T. Hyeon, Small, 2008, 4, 143-52.

[19] L. Yang, Z. Y. Gao, Y. L. Guo, W. C. Zhan, Y. Guo, Y. S. Wang, G. Z. Lu, Enzyme Microb. Technol., 2014, 60, 32-39.

[20] O. Philippova, A. Barabanova, V. Molchanov, A. Khokhlov, Eur. Polym. J., 2011, 47, 542-559.

[21] R. Y. Hong, J. H. Li, J. Wang, H. Z. Li, China Particuology, 2007, 5, 186-191.

[22] Y. H. Deng, C. C. Wang, J. H. Hu, W. L. Yang, S. K. Fu, Colloids Surf. A, 2005, 262, 87-93.

\section{Graphical Abstract}

Chin. J. Catal., 2018, 39: 47-53 doi: 10.1016/S1872-2067(17)62934-6

Immobilization of penicillin $G$ acylase on paramagnetic polymer microspheres with epoxy groups

Xing Chen, Lu Yang, Wangcheng Zhan *, Li Wang, Yun Guo, Yunsong Wang, Guanzhong Lu, Yanglong Guo* East China University of Science and Technology

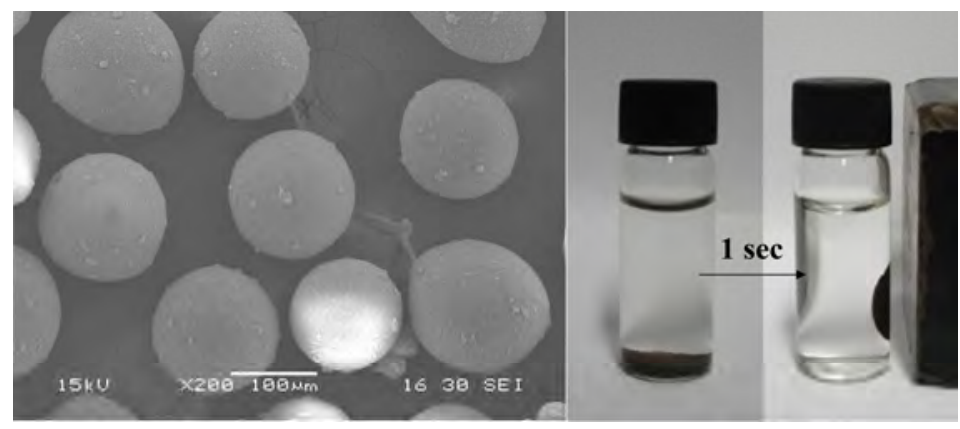

Penicillin G acylase (PGA) immobilized on paramagnetic polymer microspheres shows a high initial activity, operational stability, thermal stability, pH stability and excellent reusability. The material could be rapidly recycled with the aid of a magnet. 
[23] G. Z. Lu, P. Xue, G. W. Wuyun, Y. L. Guo, Y. S. Wang, CN Patent 1408859A, 2003.

[24] J. Hong, D. M. Xu, P. J. Gong, J. H. Yu, H. J. Ma, S. D. Yao, Microporous Mesoporous Mater., 2008, 109, 470-477.

[25] L. Lei, Y. X. Bai, Y. F. Li, L. X. Yi, Y. Yang. C. G. Xia, J. Magn. Magn. Mater., 2009, 321, 252-258.
[26] X. J. Zhang, W. Jiang, Y. F. Ye, Z. Q. Feng, Z. D. Sun, F. S. Li, L. Y. Hao, J. J. Chu, J. Magn. Magn. Mater., 2011, 323, 1440-1444.

[27] B. F. Shi, Y. Q. Wang, J. W. Ren, X. H. Liu, Y. Zhang, Y. L. Guo, Y. Guo, G. Z. Lu, J. Mol. Catal. B, 2010, 63, 50-56.

[28] A. Arslan, S. Kiralp, L. Toppare, A. Bozkurt, Langmuir, 2006, 22, 2912-2915.

\title{
青霉素G酰化酶在含环氧基团的顺磁性聚合物微球上的固定化
}

\author{
陈 星, 杨 露, 詹望成, 王 丽, 郭 耘, 王筷松, 卢冠忠, 郭杨龙 \\ 华东理工大学工业催化研究所, 上海200237
}

\begin{abstract}
摘要: 青霉素 $\mathrm{G}$ 酰化酶(PGA)是一种重要的工业生物催化剂, 常用于以青霉素 $\mathrm{G}$ 为底物生产7-氨基去乙酰氧基头孢烷酸 (7-ADCA)和6-氨基青霉烷酸(6-APA)等半合成 $\beta$-内酰胺类抗生素. 然而, PGA较差的稳定性和可重复使用性能限制了其在 工业上的广泛应用. 因此, 将PGA固定在固体载体上是很有必要的, 可以形成一种可重复使用的高性能的多相催化剂. 用 于生物酶固定化的良好载体应具备以下条件: (1)载体表面具有可用于与生物酶多点结合的高密度的官能团; (2) 载体具有 较大的比表面积以固定更多的生物酶. 通常情况下, 可以通过减小载体的粒径来增加其比表面积, 然而, 小粒径的载体很 难从反应混合液中分离出来, 造成固定化酶回收使用困难. 为了将聚合物微球的优异固定化性能与磁性纳米粒子的独特 顺磁性结合起来，我们制备了一种含环氧基团的顺磁性聚合物微球作为PGA的固定化载体. 但由于 $\mathrm{Fe}_{3} \mathrm{O}_{4}$ 纳米颗粒具有较 高的表面能, 在反相悬浮聚合反应过程中容易团聚成大颗粒, 从而导致制备的顺磁性聚合物微球的磁体含量、表面形貌和 粒径分布存在差异. 此外, $\mathrm{Fe}_{3} \mathrm{O}_{4}$ 纳米颗粒与聚合反应单体之间的相容性不好, 使得部分磁性颗粒不能很好地包埋于聚合 物微球内部, 影响固定化酶的活性和操作稳定性. 本文以 $\mathrm{N}, \mathrm{N}^{\prime}-$ 亚甲基双丙烯酰胺为交联剂, 以甲基丙烯酸缩水甘油酯和 烯丙基缩水甘油醚为功能性单体, 用反相悬浮聚合方法在 $\mathrm{SiO}_{2}$ 包覆的 $\mathrm{Fe}_{3} \mathrm{O}_{4}$ 纳米颗粒表面成功制备出含环氧基团的顺磁性 聚合物微球. 用SEM, FT-IR, XRD, VSM和低温氮气吸附等手段对含环氧基团的顺磁性聚合物微球进行了表征. 研究了 $\mathrm{SiO}_{2}$ 对 $\mathrm{Fe}_{3} \mathrm{O}_{4}$ 纳米颗粒的包覆和 $\mathrm{Fe}_{3} \mathrm{O}_{4} / \mathrm{SiO}_{2}$ 纳米颗粒的数量对于固定化酶的初始活性和操作稳定性的影响. $\mathrm{SiO}_{2}$ 在反相悬浮 聚合过程中发挥重要作用, 用 $\mathrm{SiO}_{2}$ 对 $\mathrm{Fe}_{3} \mathrm{O}_{4}$ 纳米颗粒进行亲水性改性, 有效改善了 $\mathrm{Fe}_{3} \mathrm{O}_{4}$ 纳米颗粒与聚合反应单体的相容 性, 将其引入反相悬浮聚合体系中, 可以制备得到球形度好、粒径分布均匀和超顺磁性的含环氧基团的顺磁性聚合物微 球, 其中当 $\mathrm{Fe}_{3} \mathrm{O}_{4} / \mathrm{SiO}_{2}$ 纳米颗粒的质量比为 $7.5 \%$ 时制备的含环氧基团的顺磁性聚合物微球具有最好的PGA固定化性能. PGA通过其活性非必需侧链基团一氨基与顺磁性聚合物微球表面的环氧基团的共价结合来制备顺磁性固定化酶, 该固定 化PGA的初始活性为 $430 \mathrm{U} / \mathrm{g}$ (wet), 在外加磁场的作用下容易回收使用, 重复使用 10 次后可保留 $99 \%$ 的初始活性, 具有良 好的热稳定性和酸碱稳定性, 具有较好的工业应用前景.
\end{abstract}

关键词: 顺磁性聚合物微球; 环氧基团; 青霉素G酰化酶; 共价结合; 固定化

收稿日期: 2017-08-22. 接受日期: 2017-10-13. 出版日期: 2018-01-05.

*通讯联系人. 电话/传真: (021)64252923; 电子信箱: zhanwc@ecust.edu.cn

通讯联系人. 电话/传真: (021)64252923; 电子信箱: ylguo@ecust.edu.cn

基金来源：国家自然科学基金(91545103); 上海市曙光计划(10SG30); 中央高校基本科研业务费专项资金(222201717003).

本文的电子版全文由Elsevier出版社在ScienceDirect上出版(http://www.sciencedirect.com/science/journal/18722067). 